\title{
Of Mice and Men: The Effect of Maternal Protein Restriction on Offspring's Kidney Health. Are Studies on Rodents Applicable to Chronic Kidney Disease Patients? A Narrative Review
}

\author{
Massimo Torreggiani ${ }^{1, *}$, Antioco Fois ${ }^{1}$, Claudia D'Alessandro ${ }^{2}$, Marco Colucci ${ }^{3}$, \\ Alejandra Oralia Orozco Guillén ${ }^{4}$, Adamasco Cupisti ${ }^{2}$ (D) and Giorgina Barbara Piccoli ${ }^{1,5}$ \\ 1 Nephrology and Dialysis, Centre Hospitalier Le Mans, Avenue Roubillard 194, 72000 Le Mans, France; \\ afois@ch-lemans.fr (A.F.); gbpiccoli@yahoo.it (G.B.P.) \\ 2 Department of Clinical and Experimental Medicine, University of Pisa, 56126 Pisa, Italy; \\ dalessandroclaudia@gmail.com (C.D.); adamasco.cupisti@med.unipi.it (A.C.) \\ 3 Unit of Nephrology and Dialysis, ICS Maugeri S.p.A. SB, Via S. Maugeri 10, 27100 Pavia, Italy; \\ marco.colucci89@gmail.com \\ 4 Department of Nephrology, National Institute of Perinatology "Isidro Espinoza de los Reyes", \\ Mexico City 11000, Mexico; ale_gaba@hotmail.com \\ 5 Dipartimento di Scienze Cliniche e Biologiche, Università di Torino, 10100 Torino, Italy \\ * Correspondence: maxtorreggiani@hotmail.com
}

Received: 21 April 2020; Accepted: 28 May 2020; Published: 30 May 2020

check for updates

\begin{abstract}
In the almost 30 years that have passed since the postulation of the "Developmental Origins of Health and Disease" theory, it has been clearly demonstrated that a mother's dietary habits during pregnancy have potential consequences for her offspring that go far beyond in utero development. Protein malnutrition during pregnancy, for instance, can cause severe alterations ranging from intrauterine growth retardation to organ damage and increased susceptibility to hypertension, diabetes mellitus, cardiovascular diseases and chronic kidney disease (CKD) later in life both in experimental animals and humans. Conversely, a balanced mild protein restriction in patients affected by CKD has been shown to mitigate the biochemical derangements associated with kidney disease and even slow its progression. The first reports on the management of pregnant CKD women with a moderately protein-restricted plant-based diet appeared in the literature a few years ago. Today, this approach is still being debated, as is the optimal source of protein during gestation in CKD. The aim of this report is to critically review the available literature on the topic, focusing on the similarities and differences between animal and clinical studies.
\end{abstract}

Keywords: diet; proteins; pregnancy; chronic kidney disease; nutrition

\section{Introduction}

"Der Mensch ist was er isst" (Man is what he eats) wrote Feuerbach and his observation is often cited to underline how important food is to maintaining health [1]. Moreover, our health is also influenced by what our mothers ate during pregnancy, and maternal diet appears to be a factor in some diseases.

The quantity (under- and over-nutrition) and quality of foods we eat, as well as our intake of vitamins and micronutrients, play roles that are only partially understood.

Lessons from disasters such as the famine that affected the Dutch during the Second World War [2,3] and the one that occurred during China's Great Leap Forward [4,5] in the 1960s, have clearly 
shown that brutal deprivation, even when of relatively short duration, is not without long-term consequences on kidney function. Proteinuria, hypertension and cardiovascular and kidney diseases are all reported to increase when food intake is grossly inadequate.

Conversely, overnutrition in pregnancy is associated, in the short term, with an increase in the hypertensive disorders of pregnancy and, in the long term, almost paradoxically with the same diseases we find in an under-nourished population [6-9].

Placental stress is likely to be the common pathway determining the long-term effect of these two opposite challenges (Figure 1) [10].

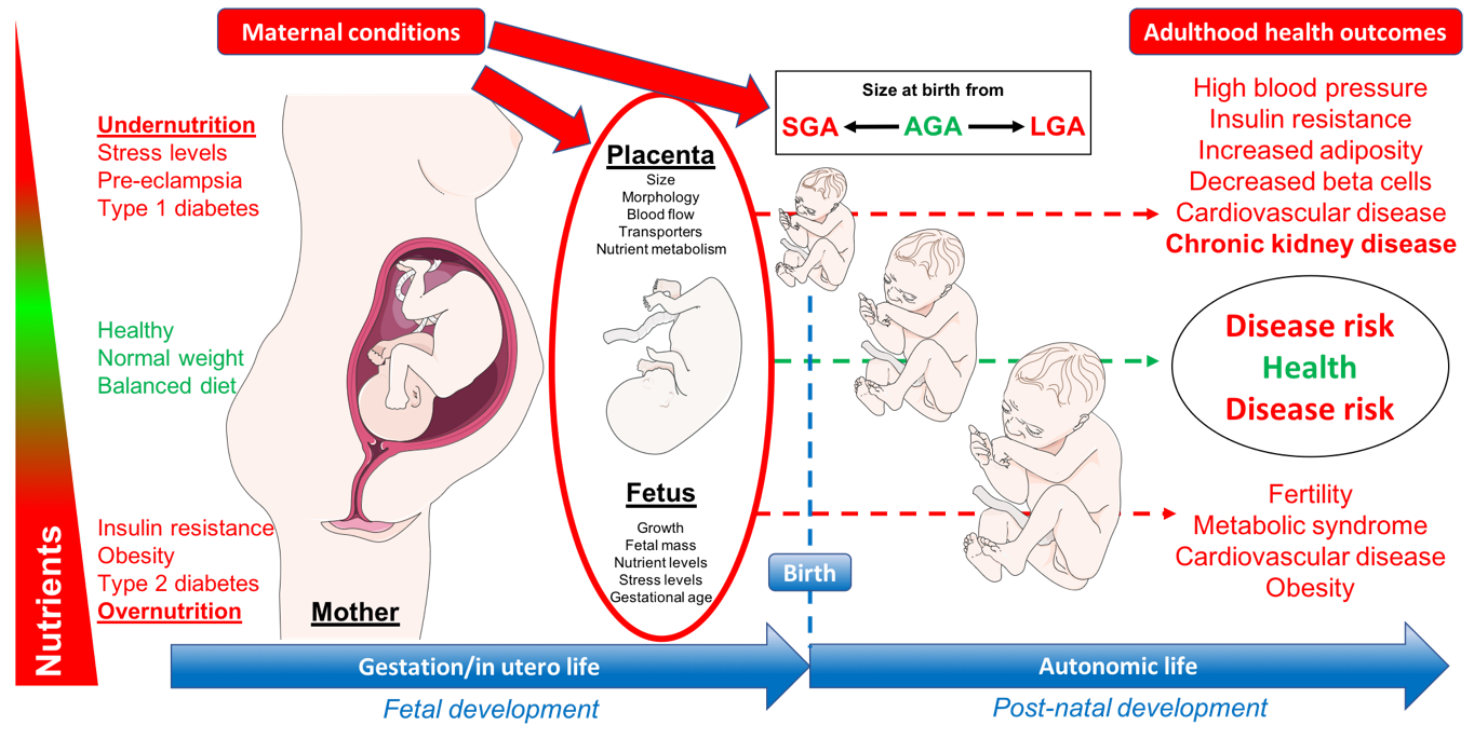

Figure 1. Effect of maternal diet during pregnancy on offspring. Adapted from Chavatte-Palmer $P$, Tarrade A, Rousseau-Ralliard D: Diet Before and During Pregnancy and Offspring Health: The Importance of Animal Models and What Can Be Learned from Them. International Journal of Environmental Research and Public Health 2016, 13. SGA: small for gestational age; AGA: adequate for gestational age; LGA: large for gestational age.

Analyzing the effect of the different factors in increasing the long-term risk of kidney diseases is not easy. Human nutrition is extremely complex, and is not limited to a mere series of protein, lipid, carbohydrate and energy counts. While during disasters undernutrition usually consists in protein deprivation, in some diseases, such as anorexia, protein intake is less affected and an energy deficit is more evident.

On the other hand, overnutrition, especially in Western countries, is associated with poor quality food, and the effects of quantity, distribution, quality and contaminants become difficult to assess. Furthermore, energy balance and gene expression are known to depend upon the intake of proteins and fat, and this modulation may have different effects on people of different genetic backgrounds [11,12].

If we are to answer at least some of these questions, we need studies employing animal models, as this will enable us to study the effects of single nutrients or of single contaminants (such as drugs or preservative agents), on a genetically identical population.

With regard to the issue discussed, the aim of the present review is to assess the role maternal protein restriction during pregnancy has in determining the offspring's future kidney health. The subject is a controversial one, as laboratory studies, mainly on rodents, usually apply a severe protein restriction and result in an increased risk of metabolic and kidney diseases in the offspring, while studies on humans are mainly performed with a moderate protein restriction and generally result in a lower risk of pregnancy complications. Conversely, we lack studies on moderate protein restriction in animals, while studies on very low protein intake in humans are usually set in a context of famine or poor access to food. 
For this reason, the review is divided into two parts: the first one regards research using animal models, while the second focuses on studies of humans. This narrative revision will analyze the following issues:

- $\quad$ Protein-restricted diets in human pregnancy and their link with chronic kidney disease (CKD);

- Rodents:

- Main experimental designs;

- Commonly used diet formulations;

○ Models of protein deprivation and their effects on offspring's kidney health.

- Humans:

- The effect on offspring of moderate protein restriction in pregnant chronic kidney disease (CKD) patients;

- The relevance of different sources of protein and whether it is scientifically acceptable to apply observations derived from animal studies to humans.

\section{The Various Aspects of Protein-Restricted Diets in Pregnancy in Humans, and Their Link with CKD}

At least for nephrologists, protein restriction is not synonymous with protein deprivation, and is usually considered to be an unintended, or extreme and unbalanced reduction in protein intake; in humans this is mainly due to lack of access, usually for economic reasons, to protein-rich foods, mainly of animal origin. In this regard, diets lacking protein are usually also deficient in other important micro and macronutrients, even though they sometimes supply enough calories.

There is a significant overlap between diets that result from a lack of resources and some vegan and plant-based diets. The deficits associated with such diets are highly variable, poorly known and depend on geographic and social context. Iron and Vitamin B12 deficits are the ones most frequently found. Overall, such diets are associated with unfavorable pregnancy outcomes, increased risk of preterm delivery, small for gestational age babies and impaired fetal growth. All these elements are, in turn, associated with a higher risk of metabolic disorders and cardiovascular and renal diseases in adulthood.

Anorexia represents a "rich" counterpart of restricted and unbalanced diets; intake of nutrients, and related deficits, vary widely: they can be multiple in the case of very restricted, rigid, repetitive diets, or there may not be any in the case of associated compulsory vitamin or micronutrient intake. The effect on offspring's health is mainly mediated by a higher incidence of preterm delivery [13].

Hyperemesis gravidarum, usually limited to the first weeks of gestation, can be considered another form of abrupt food deprivation, often associated with severe electrolyte imbalance. Pre-renal acute kidney injury may negatively influence the mother's health, but the effect on the fetus is usually minor [14].

Outside of pregnancy, moderate to severe protein restriction, when carefully controlled and supplemented if necessary, is presently recognized as the starting point for the clinical management of CKD [15].

Few experiments, most of them carried out by our multicentric group, have investigated the dietary management of women with severe CKD or relevant proteinuria in pregnancy. The diets were usually moderately restricted (protein intake between 0.6 and $0.8 \mathrm{~g} / \mathrm{kg} /$ day) and were plant based [16]. Supplementation with vitamins, amino and ketoacids was usually added. The somewhat surprising result of better intrauterine growth in pregnant chronic kidney disease (CKD) patients on such diets poses a series of questions, so far unanswered. Of these, the most important is whether the effect on maternal kidney function and on intrauterine growth is linked to protein restriction or to different protein sources (plant-based versus animal), or if it is at least partially caused by the avoidance of food additives and preservation agents frequently used in Western countries, as was suggested by two 
recent case studies [17]. The evidence from studies of patients following well-planned plant-based diets in pregnancy is reassuring, but the only clearly proven advantage is a reduction in the risk of large for gestational age babies and, possibly, of gestational diabetes [18-20]. It is, however, conceivable that other advantages, if they exist, would only be seen in a high-risk situation, like the one that characterizes CKD from its early stages [21-26].

\section{Animal Models: Protein-Restricted Diets in Pregnant Rodents}

There are two main approaches to studying protein-restricted diets in rodents: severe protein restriction, most commonly used as a method to induce fetal growth restriction, and variation of protein sources, rarely used, to mimic the dietary interventions prescribed to women.

The first, classic model, applies a severe protein restriction to the pregnant animals, often starting before mating. Table 1 shows some examples of animal feeding formulas. The "regular diet" is usually casein-based with a protein content of 18-22\%. The study diet has a protein content ranging from 4 to $10 \%$.

The aim of these models is usually to produce growth-impaired offspring, that, in keeping with the observations on humans mentioned above, are at high risk for the development of kidney abnormalities, or metabolic diseases, cardiovascular diseases, hypertension and kidney disease in adult life. Genetic background modulates the effects, and, for kidney development and diseases, these are more serious when breeds characterized by spontaneous development of CKD are employed.

The second model instead exploits different protein dietary sources in pregnant rodents to study their effects on the offspring. Soya-derived proteins are the most widely used as substitutes for casein. However, reports on pregnant animals are scant and when different protein sources are tested, the amount of total protein in the diet is similar between groups [27,28].

To date, only one study has explored the effect of diet on pregnancy in rats with CKD [29]. Cahill and colleagues studied a model of hereditary kidney cyst disease in Han:SPRD Cy rats, feeding them from two weeks before mating to the end of the weaning period, with either a soya-based or a casein-based diet. The authors found that the plant-based diet improved renal function in the pups. Moreover, renal inflammation and cell proliferation, oxidative stress and proteinuria were reduced in the offspring [29]. This study does however have several limitations: the kidney disease is a hereditary one and renal function was still in the normal range in both groups; secondly, although the sources differed, both diets contained a "normal" amount of proteins.

It is evident that none of these approaches mimic the moderate protein restriction employed for women with CKD in pregnancy. In this case, protein intake is up to $75 \%$ of a normal diet and is supplemented with keto-analogues and essential amino acids [16,30]. Keto-analogues are nitrogen-free analogues of essential amino acids that can be added to human low- and very low-protein diets $(0.6 \mathrm{~g} / \mathrm{kg} / \mathrm{day}$ of proteins and $0.3 \mathrm{~g} / \mathrm{kg} /$ day of proteins, respectively) to limit the risk of protein malnutrition [31]. 
Table 1. Examples of commercially available normal or low-protein rodent diets.

\begin{tabular}{|c|c|c|c|c|}
\hline Manufacturer & Diet & $\begin{array}{l}\text { Protein Content } \\
\quad(\mathrm{g} / \mathbf{1 0 0} \mathrm{g})\end{array}$ & $\begin{array}{l}\text { Fat Content } \\
(\mathrm{g} / 100 \mathrm{~g})\end{array}$ & $\begin{array}{l}\text { Metabolizable } \\
\text { Energy (kcal/g) }\end{array}$ \\
\hline \multicolumn{5}{|c|}{ Standard Diets } \\
\hline LabDiet & 5001Laboratory Rodent Diet & 24.1 & 5.0 & 2.9 \\
\hline Picolab & 5053 Rodent Diet 20 & 20 & 5.0 & 3.0 \\
\hline Envigo Teklad & Rodent Diet 8604 & 24.3 & 4.7 & 3.0 \\
\hline Altromin & C1000 & 20.0 & 13.0 & 3,5 \\
\hline $\begin{array}{l}\text { American Institute } \\
\text { of Nutrition [32] }\end{array}$ & $\begin{array}{l}\text { AIN-93G Rodent Diet for Growth, } \\
\text { Pregnancy and Lactation }\end{array}$ & 19.3 & 16.7 & 3.8 \\
\hline $\begin{array}{l}\text { American Institute } \\
\text { of Nutrition [32] }\end{array}$ & $\begin{array}{l}\text { AIN-93M Rodent Diet for } \\
\text { Maintenance }\end{array}$ & 14.1 & 10.0 & 3.6 \\
\hline \multicolumn{5}{|c|}{ Low-protein Diets } \\
\hline Envigo Teklad & TD90016 & 6.0 & 5.5 & 3.8 \\
\hline Altromin & C1003 & 9.0 & 13.0 & 3.6 \\
\hline
\end{tabular}

Data from manufacturers' websites, accessed on February 10, 2020. LabDiet: https://www.labdiet.com/cs/groups/ lolweb/@labdiet/documents/web_content/mdrf/mdi4/ \{\}edisp/ducm04_028021.pdf; Picolab: http://www.petfoods. com.mx/PetFoods/LabDiet_ifo_files/5053.pdf; Envigo Teklad: https://www.envigo.com/resources/brochures/rodentdiet-and-ingredient-comparison.pdf; https://www.envigo.com/resources/data-sheets/90016.pdf; Altromin: https: //altromin.com/pdf/en/C1000; https://altromin.com/pdf/en/C1003.

\section{Models of Protein Deprivation during Pregnancy in Rodents and Kidney Health in Offspring}

The earliest studies on low-protein diets in rodents date back to the 1930s [33]. In the Sixties, Zeman observed smaller kidneys with a reduced number of glomeruli in the offspring of dams fed an LPD [34] and undertook a series of experiments to investigate this phenomenon and distinguish it from the effects of calorie restriction during pregnancy [35]. He also hypothesized that smaller kidneys lead to reduced kidney function later in life [35].

In keeping with this observation, in 1988 Brenner proposed that a lower nephron endowment at birth confers increased salt sensitivity and a higher risk of hypertension during adulthood [36].

In 1993, Barker observed the relationship with gestational undernutrition and diseases that develop later in life and formulated the theory of "Developmental Origins of Health and Disease" [37]. Since then, a large body of evidence has been gathered from studies using animal models.

In the 1990s, Langley-Evans produced a series of studies showing that fetal programming by means of a severely protein-restricted maternal diet leads to hypertension, which could be prevented by a blockade of glucocorticoid production [38] or administration of ACE inhibitors to pups [39]. This increase in blood pressure could be, at least in part, caused by an alteration of the normal angiotensin II receptor ratio. In fact, in the kidney cortex of Wistar rat pups whose dams had been fed a severely protein-restricted diet, AT1 receptors were about $62 \%$ higher, while AT2 receptors were about $35 \%$ lower, with no change in angiotensin II tissue levels or circulating aldosterone levels [40]. Even when a protein-deprived diet was administered only in the second half of pregnancy, the offspring exhibited a higher expression of AT1 receptors and decreased expression of AT2 receptors in the heart [41]. Increased oxidative stress and inflammatory renal cell infiltration contribute to hypertension programming. Increased renal oxidation markers before hypertension onset has been observed in the offspring of mothers fed a low-protein diet during gestation and the administration of antioxidants or mycophenolate during the prehypertensive window was able to prevent high blood pressure in adulthood [42]. These findings were recently corroborated by experiments in which renin-angiotensin system inhibitors were administered after weaning: losartan eliminated inflammatory infiltration and intrarenal renin-angiotensin system (RAS) activation [43] while transient exposure to enalapril reduced glomerular filtration rate (GFR) and prevented the onset of hypertension [44]. Moreover, a role for renal nerves in sodium reabsorption has been postulated: bilateral renal denervation in the offspring of 
dams fed a low-protein diet was able to increase the fractional excretion of sodium, thereby mitigating the rise of blood pressure [45].

Experimental data suggest that protein restriction timing during gestation influences the severity of hypertension in offspring: feeding dams with a low-protein diet during discrete time frames (i.e., early, mid or late pregnancy) resulted in hypertensive pups but the highest blood pressure levels were observed in pups whose mothers were given a low-protein diet for the entire duration of gestation [46].

In addition, it was observed that severe protein restriction during pregnancy decreased offspring's life span [47] and impaired nephrogenesis [48], in accordance with Brenner's hypothesis [49]. The reason why severe protein restriction in the mother turns into a reduced number of glomeruli at birth (20\% to $30 \%$ fewer glomeruli than in controls) $[50,51]$ has been explained as an imbalance between actively proliferating cells and apoptosis in the metanephros, in favor of apoptosis [51] and with higher p53 expression [52]. Moreover, protein deprivation from conception to the 5th-6th week of gestation alters gene expression in embryonic kidneys, downregulating the expression of prox- 1 and cofilin-1, the genes that are pivotal in the normal development of the lymphatic vessels [53] and cytoskeleton [54], respectively [55]. In addition, experimental studies with severe protein restriction in sheep, demonstrated impaired fetal renal microvascular development [56].

Although kidney damage during embryogenesis leads to hypertension during adulthood, the window for programming can extend to the postnatal period and appears to be susceptible to treatment. It was found that feeding the offspring of female rats kept on a low-protein diet during pregnancy, a low-sodium diet or administrating an ACE inhibitor for a short time after weaning was able to prevent a subsequent rise in blood pressure even after discontinuation of treatment [57]. Moreover, cross-fostering pups generated by dams fed a regular $20 \%$ protein diet to mothers fed a severely protein-restricted diet, during lactation, resulted in hypertension even in the absence of fetal programming [58]. Conversely, it has been shown that cross-fostering the offspring of mothers with protein malnutrition in pregnancy to mothers fed a normal protein diet was able to normalize the number of glomeruli and normalize blood pressure to the values found in control male rats [59].

However, renal physiology in rodents is different than in humans, as in rodents kidney maturation continues after birth [60-63] while in humans it ceases by the 36th week of gestation in at-term infants [64] and there is evidence that nephrogenesis continues until the 40th post-natal day only in preterm neonates in whom, however, nephrons remain abnormal [65].

Protein restriction during pregnancy affects male and female offspring differently $[66,67]$. For instance, hypertension in pups from dams fed a protein-restricted diet has been shown to be glucocorticoid-dependent in males but not in females. The underlying mechanism seems to be a reduced expression of renal AT2 receptors [68]. In addition, male pups from mothers fed a severely protein-restricted diet showed impaired sexual maturation, prostate growth and reproductive ability $[69,70]$. Similarly, severe maternal protein restriction has been associated with a reduced ovarian reserve in female offspring [71]. These results support the importance of studying the F3 generation, which is the first one not influenced by the mother's diet during pregnancy, in order to understand the transgenerational effect of gestational protein restriction on kidney structure and function [72] (Figure 2).

Hypertension is not the only cardiovascular risk factor that has been observed in offspring exposed to severe protein restriction in utero: insulin resistance [73], reduced insulin secretion [74] and insulin signaling deregulation [75], reduced pulmonary compliance and higher tissue elastance [76], altered lipid metabolism [77], fatty liver disease [78], cardiac fibrosis [79] and cardiac oxidative stress [80], muscle fiber and neuromuscular junction changes [81], metabolic syndrome [82], altered fat distribution [83], increased susceptibility to vascular injury [84], and alteration of coagulation factors [85] have all been described. 
Fo

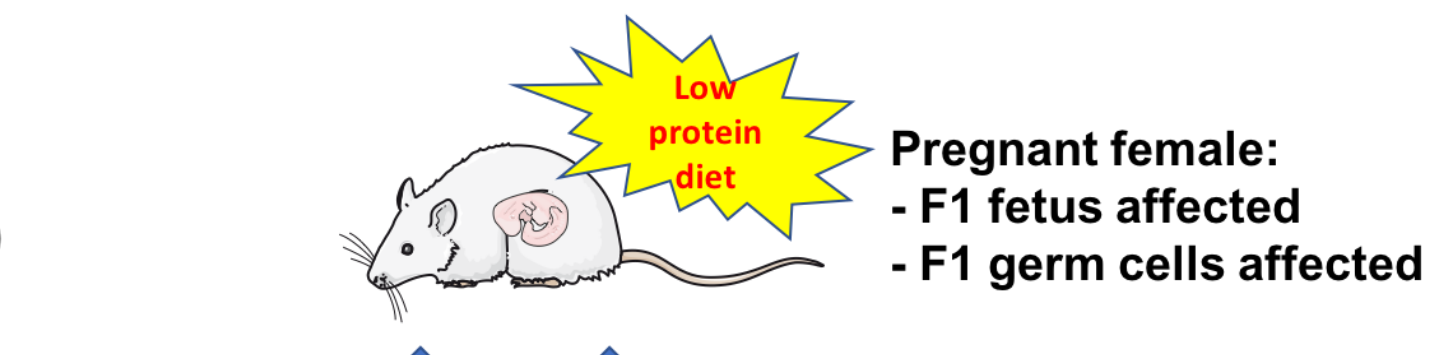

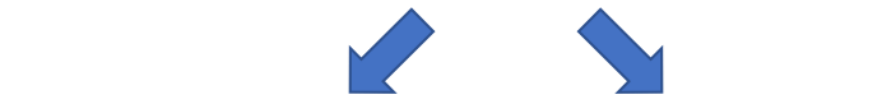

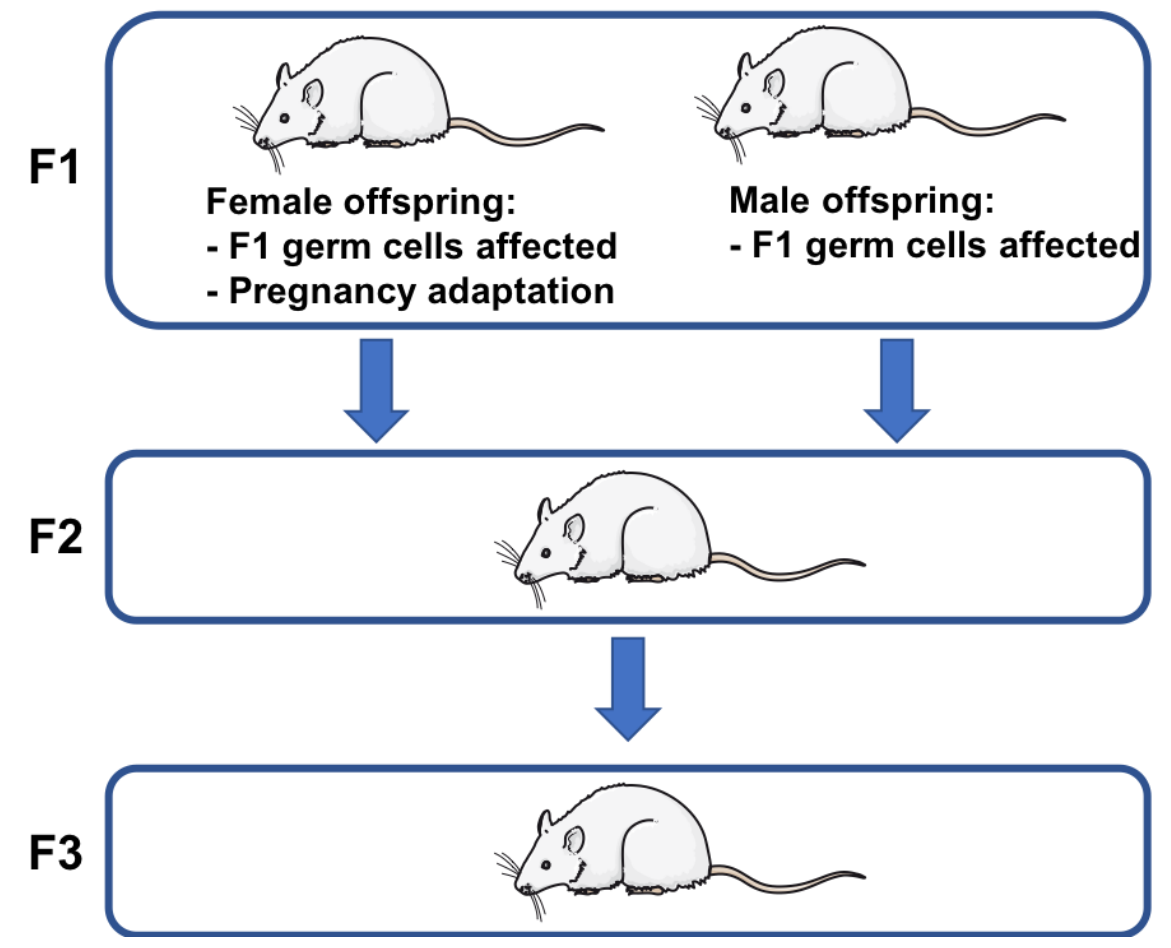

Figure 2. Transgenerational programming. Adapted from Briffa JF, Wlodek ME, Moritz KM. Transgenerational programming of nephron deficits and hypertension. Seminars in Cell and Developmental Biology. 2018, Jun 7.

Severe protein restriction in pregnancy can also influence drug response in the offspring. DuBois reported an impaired response to furosemide in programmed Sprague Dawley female rats due to increased renal organic anion transporter 1, irrespective of body weight, an important notion in drug dosing for physicians [86]. In addition, epithelial sodium channel (ENaC) activity, as well as sodium-potassium-chloride cotransporter (NKCC2) activity in the cortical collecting ducts seem to be caused by severe maternal protein restriction, which potentially affects renal sodium handling. The administration of the $\mathrm{ENaC}$ inhibitor benzamil, indirectly showed that basal ENaC activity was higher in pups from protein-deprived dams compared to controls [87]. In addition, maternal protein deprivation resulted in increased NKCC2 abundance in the renal medulla and increased chloride transport in the thick ascending limb of the Henle's loop in their offspring [88].

Maternal protein restriction has also been shown to increase sodium urinary loss [89] and determine an increment of total body sodium content and extracellular fluid volume expansion in the offspring [90]. In order to explain these apparently contrasting observations, Alwasei and colleagues proposed that increased sodium reabsorption in the kidney of the offspring of dams fed a protein-restricted diet is an adaptation to sodium loss due to prenatal injury and sodium losses also stimulate an appetite for salt and increased food intake that lead to accelerated growth and hypertension [90]. 
The kidneys of pups exposed to severe protein restriction during gestation also showed impaired calcium handling with a decreased passive reabsorption in the proximal tubule, leading to a reduction in femur trabecular bone mass [91].

Finally, it is worth mentioning that there are a small number of studies that were not able to demonstrate the effects of fetal programming by means of severe protein restriction during pregnancy. According to Jones and colleagues, a programmed lower nephron endowment did not influence the onset of kidney disease in diabetic Wistar rats [92]. Zimanyi and colleagues, instead, did not confirm the onset of hypertension and did not find correlations between total filtration surface area and blood pressure in adulthood in pups from Wistar Kyoto dams fed a severe protein-restricted diet during pregnancy and lactation [93]. These results led the authors to suggest that a lower nephron endowment is not sufficient to induce hypertension in adulthood but that these animals are more susceptible to a "second hit". In fact, although not different from controls in basal conditions, the infusion of advanced glycation end-products (AGEs) in the offspring increased the expression of profibrotic genes and the accumulation of AGEs in the kidney, suggesting increased susceptibility to the development of diabetic nephropathy [94].

Severe protein restriction has been found to alter placental morphology and function in animal models. Several alterations have been described, including reduced vascularization due to increased proinflammatory cytokine secretion by immune cells [95], reduced weight with smaller junctional zone [96], reduced trophoblast giant cells and trophoblast glycogen cells [97], higher oxygen uptake by placental mitochondria that may reflect the uncoupling of respiration and oxidative phosphorylation [98] and downregulated amino acid transport [99].

\section{Experience in Human CKD Pregnancies with Moderate Protein Restriction and Modulation of Protein Quality}

Human pregnancies, like all mammal pregnancies, are characterized by an increased demand for energy and macro- and micro-nutrients. Accordingly, it is generally suggested that protein intake should be increased to meet metabolic requirements. It is recommended that normal protein intake of $0.7-0.9 \mathrm{~g} / \mathrm{kg} /$ day should be increased by $1 \mathrm{~g} /$ day during the first trimester, then by a further $8 \mathrm{~g}$ per day in the second trimester, and $23-29 \mathrm{~g}$ in the third $[100,101]$. The modulation of these indications in pregnant women with CKD is not fully agreed but several reports indicate that, in the presence of $\mathrm{CKD}$, a moderate protein restriction might be useful and safe for mother and offspring. The first study of pregnant CKD patients put on moderately protein-restricted diets was published almost a decade ago [17]. Originating as an attempt to balance the contrasting nutritional needs of advanced CKD and pregnancy, 12 pregnancies in 11 patients with CKD stages 3 to 5 and/or proteinuria ( $>1 \mathrm{~g} /$ day), were managed with a $0.6-0.7 \mathrm{~g} / \mathrm{kg} /$ day vegetarian protein diet with keto-analogue supplementation at increasing dosage throughout gestation. The authors observed no major side effects of this diet and only one pregnancy, in the context of nephrotic syndrome, was terminated. Ten of the 11 babies born were delivered preterm, two were small for gestational age but after birth, the growth curve of all the babies was normal. None of the mothers started dialysis during pregnancy or in the year after delivery [17]. In a subsequent study, these authors applied the same dietary protocol to 24 pregnancies, with 21 control CKD pregnancies with no dietary restrictions [25]. Notably, the number of small for gestational age babies was significantly lower in the diet group than in controls. A follow-up study of the babies from six months to ten years of age found no socialization or schooling problems and similar rates of hospitalization [25]. Expanding the sample size of both cases and controls confirmed the results [22]. These studies included a large spectrum of renal diseases: diabetic nephropathy, glomerulonephritis, kidney transplant, genetic diseases [17,22,25]. In a small, more homogeneous series of patients affected by biopsy-proven focal segmental glomerulosclerosis, with normal kidney function and proteinuria, mothers on the same diet delivered at-term healthy babies without consequences to babies' growth [21]. Other case reports confirm this trend [102], demonstrating the difference between 
a controlled diet compared to the "famine" model and the importance of dietary education in order to improve adherence [103].

\section{What Are the Best Sources of Protein}

The differences in quality and properties of animal- and plant-derived protein are summarized in Table 2. Notably, plant-derived proteins are associated with lower phosphate bioavailability [104,105], are less likely to induce acidosis [106], favorably modulate gut microbiota leading to reduced production of uremic toxins $[107,108]$, and are rich in antioxidants. Conversely, animal-derived proteins supply all the essential amino acids. Overall, there are no indications that a plant-based diet is not appropriate in pregnancy. In fact, according to the United States Academy of Nutrition and Dietetics, "Well-designed vegetarian diets provide adequate nutrient intakes for all stages of the life cycle and can also be useful in the therapeutic management of some chronic diseases" [19].

While data on plant-based protein diets were associated with lower mortality in patients with CKD after adjusting for comorbidities and risk factors [109], vegetarian diets during pregnancy carry a risk of nutritional deficits: vitamins B12 [110,111] and D [112], and iron [113] and zinc [114] deficits have been described but these can easily be corrected by close monitoring and well-planned supplementation. These deficits are also common among non-vegetarian mothers and it has been found that vegetarian patients are more compliant in taking supplements [113]. Plant-based diets do not seem to affect pregnancy-related disorders: the incidence of preeclampsia and preterm delivery has been described as equal or lower [115-119] whereas glycemic control seems to be improved by fiber-rich diets [120]. Although we lack proof that a plant-based diet is more beneficial than an omnivorous one, no significant harm was observed.

Soya is the source of vegetable protein most studied in nephrology. Soybeans are a complete source of amino acids, comparable to meat, for which they can serve as a valuable substitute [121]. In renal patients, soya-based diets have been shown to have positive effects on plasma cholesterol and triglycerides [122,123], serum creatinine and phosphates [122], oxidation markers and endothelial function [124,125], glucose metabolism [126] and proteinuria [127-129]. Extensive studies on isoflavones, the polyphenolic group of compounds found in soybeans, have shown that they exhibit anti-inflammatory, anticancer, antioxidant and antimicrobial activity [130]. Among them, genistein and daidzein have a structure similar to estradiol and are classified as phytoestrogens because of their affinity for the estrogen receptor [131]. It is worth mentioning, however, that isoflavone metabolism is mediated by the kidney: patients on dialysis show a longer half-life of genistein and daidzein and dialysis clearance is minimal [132].

In pregnant, non-CKD women, soya-based diets have been found to ameliorate glucose homeostasis, lipid profile and antioxidant reserves [133].

The effect of the diet in humans may, however, depend on genetic background, as happens in rodents. In fact, a Canadian study showed that a plant-based diet during pregnancy was associated with a higher risk of delivering small for gestational age babies among European-origin mothers and increased neonatal birth weight among Canadian mothers of South Asian origin [134]. 
Table 2. Main differences between the nutritional profiles of plant- and animal-derived protein patterns.

\begin{tabular}{|c|c|c|}
\hline & Plant-Based Protein Pattern & Animal Protein Pattern \\
\hline Energy & No difference & No difference \\
\hline Essential amino acids & $\begin{array}{l}\text { Lacking in methionine and cysteine } \\
\text { (lack can be overcome by combining } \\
\text { cereals with legumes) }\end{array}$ & All present \\
\hline Fats & Low, mostly unsaturated & High, mostly saturated \\
\hline Fiber & High & Low \\
\hline Iron & $\begin{array}{l}\text { Non-heme iron } \\
\text { (reduced bioavailability; Phytic acid and } \\
\text { fibers reduce absorption; vitamin C may } \\
\text { favor absorption) }\end{array}$ & $\begin{array}{c}\text { Heme iron } \\
\text { (high bioavailability) }\end{array}$ \\
\hline Sodium & Low & High \\
\hline Potassium & $\begin{array}{c}\text { High } \\
\text { (cooking methods may reduce content) } \\
\text { Moderate }\end{array}$ & Low \\
\hline Phosphate & $\begin{array}{l}\text { (in the form of phytic acid, so less easily } \\
\text { absorbed) }\end{array}$ & High \\
\hline Production of uremic toxins & Low & High \\
\hline Antioxidants & High & Low \\
\hline Vitamin $B_{12}$ & Low & High \\
\hline Calcium & $\begin{array}{c}\text { Low } \\
\text { (phytic acid and fibers reduce absorption) }\end{array}$ & Low, high only in dairy foods \\
\hline Folate & $\begin{array}{l}\text { High } \\
\text { (cooking methods may reduce content) }\end{array}$ & Low \\
\hline Magnesium & High & Low \\
\hline Zinc & Low & High \\
\hline
\end{tabular}

\section{What Rodent Models Cannot Show Us about Protein Restriction in Human Pregnancy}

Although animal models are a cornerstone of experimental research they are far from perfect [135]. Most importantly, protein restriction in pregnant animal models is extreme, between $50 \%$ and $70 \%$ of the normal protein diet. This configures a model of protein deprivation rather than protein restriction, which is hardly comparable to studies on humans in which protein intake is reduced by a maximum of $25 \%$ below baseline.

Secondly, renal development in rodents extends after birth. This differs from humans in whom kidney development is complete by the $36^{\text {th }}$ week of gestation. Moreover, not all rodent strains are equally susceptible to kidney injury, thus the choice of model is critical [136,137]. In addition, severe protein restriction can affect housekeeping gene expression in the offspring, making it crucial to select the reference gene when analyzing genome transcripts [138]. In rodents, the catch-up growth of offspring with intrauterine growth restriction seems to be crucial for developing disease during adulthood [139-142]. In this context, catch-up growth may be a "second hit" revealing the increased susceptibility of fetal programming, as the offspring would not be able to cope with an increased nutrient intake [143,144].

Finally, despite the large number of models of kidney injury in pregnancy, there are no murine models for chronic kidney disease focusing on maternal diet.

Protein sources during pregnancy are likely to influence offspring health but few studies have addressed this issue. A favorable effect of soya-based compared to casein-based diets has been described in rats in regard to renal inflammation, oxidative stress and endothelial function [29,145].

For humans, our experience is scant. Processed red meat has been associated with the worst outcomes in terms of kidney disease: the generation $\mathrm{R}$ study showed that protein intake during the first trimester of pregnancy correlated with renal function in offspring; however, when assessing the different contributions of protein sources, this association was confirmed for vegetable-derived protein but not for animal-derived protein intake [146]. 


\section{Future Directions}

Research employing animal models is warranted as it will enable us to determine whether a moderate protein restriction during pregnancy in CKD is beneficial.

Theoretically, pregnancy in chronic kidney disease should be studied in experimental models of glomerulonephritis [147] as well as in the setting of a reduction of the renal mass [148,149].

The design we propose is to evaluate the effects of a plant-based, moderately protein-restricted diet during pregnancy and lactation in Wistar rats undergoing 5/6 nephrectomy before mating (thus with moderate kidney function impairment at the time of conception). Pregnancies would be evaluated in terms of abortions, miscarriages, premature delivery, worsening of kidney function or dam's death. Offspring would be evaluated in regard to body and kidney weight (and their ratio), renal function, presence of physical abnormalities, ability to thrive and develop normally. If possible, the effect of the diet would also be studied in the second and third generation fed different diets (Figure 3).

Fo
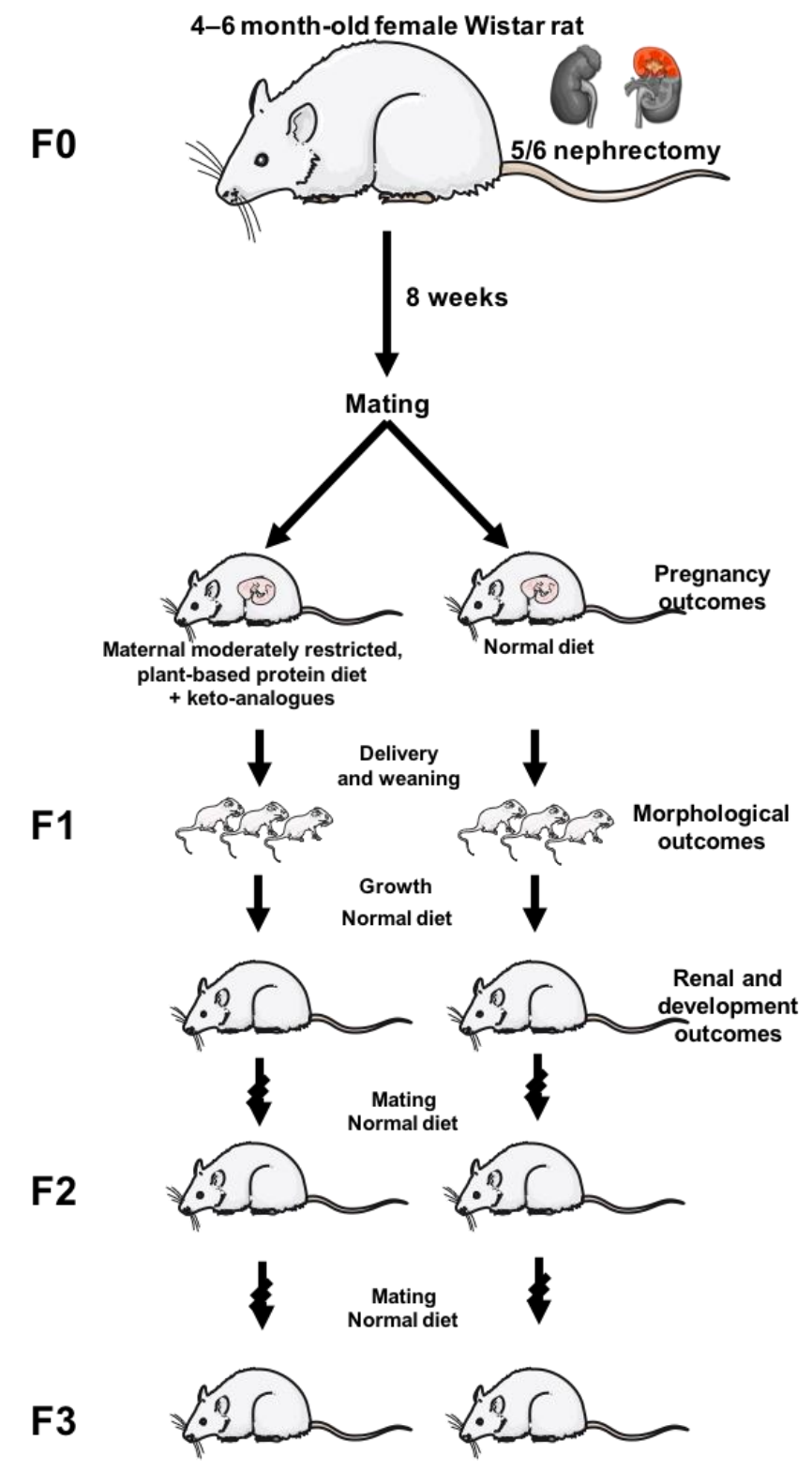

Figure 3. Design of a potential study to test the effectiveness of a moderately reduced-protein, vegetarian, supplemented diet in an animal model of chronic kidney disease. 


\section{Lessons for Clinical Nephrologists}

Nephrologists routinely refer to animal models to better understand the pathophysiology and management of kidney diseases. While this approach is pivotal to safely translating basic scientific observations into clinical practice, in some cases, such as the one being discussed, it may be misleading.

Acknowledging the difference between animal models and human situations is crucial if we are to avoid seeing every type of protein restriction in pregnancy as negative.

A semantic problem exists, since the same terms indicate different interventions: "low-protein diets" in rodents are usually synonymous with highly-restricted diets, bordering on protein deprivation; conversely in humans, a "low-protein diet" identifies a protein restriction of 20-25\%, often supplemented with essential amino acids or keto-analogues. In this respect, generalization of the current findings in animal models to human pregnancies is not possible. Even in the absence of solid pre-clinical studies, however, some reports indicate that the management of CKD pregnant patients with a balanced, moderate protein restriction is safe and may decrease gestational complications without increasing the risk of renal disease progression in the mother. Larger human studies, and research using animal models are needed to corroborate these promising results (Table 3).

Table 3. Key points for clinical nephrologists.

\begin{tabular}{|c|c|}
\hline Rodents & Humans \\
\hline \multicolumn{2}{|c|}{$\begin{array}{l}\text { Severe maternal protein deprivation during pregnancy is detrimental for offspring and leads to an increased risk of } \\
\text { cardiovascular and metabolic diseases later in life. }\end{array}$} \\
\hline & $\begin{array}{l}\text { A moderate protein restriction in CKD patients has } \\
\text { proved to retard the progression of chronic kidney } \\
\text { disease and control uremic symptoms [15]. }\end{array}$ \\
\hline $\begin{array}{l}\text { Protein restriction in pregnant animal models is usually } \\
\text { severe (50-70\%) and unbalanced. }\end{array}$ & $\begin{array}{l}\text { A vegan/vegetarian diet with a } 20-25 \% \text { protein restriction } \\
\text { supplemented with keto-analogues in pregnant CKD } \\
\text { patients is safe for the mother and the offspring and may } \\
\text { help control renal disease without consequences for the } \\
\text { newborn [21-26]. }\end{array}$ \\
\hline \multicolumn{2}{|l|}{$\begin{array}{l}\text { Consequences of a poor maternal diet on offspring's } \\
\text { health could extend as far as the third generation [72]. }\end{array}$} \\
\hline \multicolumn{2}{|c|}{ Genetic background and gender modulate the effects of maternal diet on the offspring $[66,67,134]$. } \\
\hline \multicolumn{2}{|l|}{$\begin{array}{l}\text { There are no studies on diet in pregnant rodents } \\
\text { with CKD. }\end{array}$} \\
\hline $\begin{array}{l}\text { Further research on animal models is needed to better } \\
\text { elucidate the mechanisms and long-term consequences } \\
\text { on offspring of a moderate protein restriction during } \\
\text { pregnancy in CKD in a controlled environment }\end{array}$ & $\begin{array}{l}\text { Longer follow-up studies are needed to study the effects } \\
\text { of a moderate maternal protein restriction in the course of } \\
\text { CKD pregnancy on offspring's health in adulthood. }\end{array}$ \\
\hline
\end{tabular}

\section{Conclusions}

Severe protein restriction in pregnancy is detrimental for kidney health, in particular if genetic background already predisposes to CKD; there is full agreement between rodents and humans in this respect. However, in pregnant patients affected by CKD, a moderate protein restriction, with a well-planned plant-based diet can be safe for both mother and offspring, decreasing the incidence of pregnancy complications and producing an expected positive effect on offspring's kidney health.

Author Contributions: G.B.P. and M.T.; Draft and design: G.B.P. and M.T.; Bibliographic search: G.B.P., M.T., A.F., M.C. and A.O.O.G.; Figures and tables: M.T. and M.C.; Control and discussion: A.C., C.D. and A.O.O.G. Final review and approval: all authors. All authors have read and agreed to the published version of the manuscript.

Funding: This research received no external funding. The Centre Hospitalier Le Mans covered editing and publication expenses.

Acknowledgments: To Susan Finnel for her careful language review.

Conflicts of Interest: No author has a conflict of interest. 


\section{References}

1. Cherno, M. Feuerbach's "Man is what He Eats": A Rectification. J. Hist. Ideas 1963, 24, 397. [CrossRef]

2. Roseboom, T.J.; Van Der Meulen, J.H.P.; Osmond, C.; Barker, D.J.P.; Ravelli, A.C.J.; Schroeder-Tanka, J.M.; van Montfrans, G.A.; Michels, R.P.J.; Bleker, O.P. Coronary heart disease after prenatal exposure to the Dutch famine, 1944-1945. Heart 2000, 84, 595-598. [CrossRef] [PubMed]

3. Painter, R.; Roseboom, T.J.; Van Montfrans, G.A.; Bossuyt, P.M.; Krediet, R.T.; Osmond, C.; Barker, D.J.; Bleker, O.P. Microalbuminuria in Adults after Prenatal Exposure to the Dutch Famine. J. Am. Soc. Nephrol. 2004, 16, 189-194. [CrossRef] [PubMed]

4. Huang, C.; Guo, C.; Nichols, C.; Chen, S.; Martorell, R. Elevated levels of protein in urine in adulthood after exposure to the Chinese famine of 1959-61 during gestation and the early postnatal period. Int. J. Epidemiol. 2014, 43, 1806-1814. [CrossRef] [PubMed]

5. Wang, N.; Ning, Z.; Xia, F.; Chen, C.; Cheng, J.; Chen, Y.; Lu, Y. Exposure to famine in early life and chronic kidney diseases in adulthood. Nutr. Diabetes 2018, 8, 4. [CrossRef] [PubMed]

6. De Campos, K.E.; Sinzato, Y.; Pimenta, W.D.P.; Rudge, M.V.C.; Damasceno, D.C. Effect of maternal obesity on diabetes development in adult rat offspring. Life Sci. 2007, 81, 1473-1478. [CrossRef]

7. Wong, M.G.; The, N.L.; Glastras, S. Maternal obesity and offspring risk of chronic kidney disease. Nephrology 2018, 23, 84-87. [CrossRef]

8. Perng, W.; Oken, E. Maternal obesity and associated offspring diabetes mellitus. Nat. Rev. Endocrinol. 2019, 15, 630-632. [CrossRef]

9. Langley-Evans, S.C. Fetal programming of CVD and renal disease: Animal models and mechanistic considerations. Proc. Nutr. Soc. 2013, 72, 317-325. [CrossRef]

10. Chavatte-Palmer, P.; Tarrade, A.; Rousseau-Ralliard, D.R. Diet before and during Pregnancy and Offspring Health: The Importance of Animal Models and What Can Be Learned from Them. Int. J. Environ. Res. Public Health 2016, 13, 586. [CrossRef]

11. Pezeshki, A.; Zapata, R.; Singh, A.; Yee, N.J.; Chelikani, P. Low protein diets produce divergent effects on energy balance. Sci. Rep. 2016, 6, 25145. [CrossRef] [PubMed]

12. Haro, D.; Marrero, P.F.; Relat, J. Nutritional Regulation of Gene Expression: Carbohydrate, Fat and Amino Acid-Dependent Modulation of Transcriptional Activity. Int. J. Mol. Sci. 2019, 20, 1386. [CrossRef] [PubMed]

13. Mantel, Ä.; Hirschberg, A.L.; Stephansson, O. Association of Maternal Eating Disorders With Pregnancy and Neonatal Outcomes. JAMA Psychiatry 2020, 77, 285. [CrossRef] [PubMed]

14. Nwoko, R.; Plećaš, D.; Garovic, V.D. Acute kidney injury in the pregnant patient. Clin. Nephrol. 2012, 78, 478-486. [CrossRef]

15. Mitch, W.E.; Remuzzi, G. Diets for patients with chronic kidney disease, should we reconsider? BMC Nephrol. 2016, 17, 80. [CrossRef]

16. Reyes-López, M.A.; Piccoli, G.B.; Leone, F.; Orozco-Guillén, A.; Perichart-Perera, O. Nutrition care for chronic kidney disease during pregnancy: An updated review. Eur. J. Clin. Nutr. 2020, 1-8. [CrossRef]

17. Piccoli, G.B.; Attini, R.; Vasario, E.; Gaglioti, P.; Piccoli, E.; Consiglio, V.; Deagostini, C.; Oberto, M.; Todros, T.; Reddy, A.S.; et al. Vegetarian supplemented low-protein diets. A safe option for pregnant CKD patients: Report of 12 pregnancies in 11 patients. Nephrol. Dial. Transplant. 2010, 26, 196-205. [CrossRef]

18. Pistollato, F.; Cano, S.S.; Elío, I.; Vergara, M.M.; Giampieri, F.; Battino, M. Plant-Based and Plant-Rich Diet Patterns during Gestation: Beneficial Effects and Possible Shortcomings. Adv. Nutr. 2015, 6, 581-591. [CrossRef]

19. Melina, V.; Craig, W.; Levin, S. Position of the Academy of Nutrition and Dietetics: Vegetarian Diets. J. Acad. Nutr. Diet. 2016, 116, 1970-1980. [CrossRef]

20. Piccoli, G.B.; Leone, F.; Attini, R.; Cabiddu, G.; Loi, V.; Maxia, S.; Capizzi, I.; Todros, T. Vegetarian and Plant-Based Diets in Pregnancy. In Vegetarian and Plant-Based Diets in Health and Disease Prevention; Mariotti, F., Ed.; Academic Press: Cambridge, MA, USA, 2017.

21. Attini, R.; Leone, F.; Montersino, B.; Fassio, F.; Minelli, F.; Colla, L.; Rossetti, M.M.; Rollino, C.; Alemanno, M.G.; Barreca, A.; et al. Pregnancy, Proteinuria, Plant-Based Supplemented Diets and Focal Segmental Glomerulosclerosis: A Report on Three Cases and Critical Appraisal of the Literature. Nutrients 2017, 9, 770. [CrossRef] 
22. Attini, R.; Leone, F.; Parisi, S.; Fassio, F.; Capizzi, I.; Loi, V.; Colla, L.; Rossetti, M.; Gerbino, M.; Maxia, S.; et al. Vegan-vegetarian low-protein supplemented diets in pregnant CKD patients: Fifteen years of experience. BMC Nephrol. 2016, 17, 132. [CrossRef] [PubMed]

23. Cabiddu, G.; Castellino, S.; Gernone, G.; Santoro, D.; Giacchino, F.; Credendino, O.; Daidone, G.; Gregorini, G.; Moroni, G.; Attini, R.; et al. Best practices on pregnancy on dialysis: The Italian Study Group on Kidney and Pregnancy. J. Nephrol. 2015, 28, 279-288. [CrossRef] [PubMed]

24. Piccoli, G.B.; Clari, R.; Vigotti, F.; Leone, F.; Attini, R.; Cabiddu, G.; Mauro, G.; Castelluccia, N.; Colombi, N.; Capizzi, I.; et al. Vegan-vegetarian diets in pregnancy: Danger or panacea? A systematic narrative review. BJOG: Int. J. Obstet. Gynaecol. 2015, 122, 623-633. [CrossRef] [PubMed]

25. Piccoli, G.B.; Leone, F.; Attini, R.; Parisi, S.; Fassio, F.; Deagostini, M.C.; Ferraresi, M.; Clari, R.; Ghiotto, S.; Biolcati, M.; et al. Association of Low-Protein Supplemented Diets with Fetal Growth in Pregnant Women with CKD. Clin. J. Am. Soc. Nephrol. 2014, 9, 864-873. [CrossRef]

26. Attini, R.; Montersino, B.; Leone, F.; Minelli, F.; Fassio, F.; Rossetti, M.M.; Colla, L.; Masturzo, B.; Barreca, A.; Menato, G.; et al. Dialysis or a Plant-Based Diet in Advanced CKD in Pregnancy? A Case Report and Critical Appraisal of the Literature. J. Clin. Med. 2019, 8, 123. [CrossRef]

27. Jahan-Mihan, A.; Smith, C.E.; Hamedani, A.; Anderson, G.H. Soy protein-based compared with casein-based diets fed during pregnancy and lactation increase food intake and characteristics of metabolic syndrome less in female than male rat offspring. Nutr. Res. 2011, 31, 644-651. [CrossRef]

28. Jahan-Mihan, A.; Szeto, I.M.Y.; Luhovyy, B.L.; Huot, P.; Anderson, G.H. Soya protein- and casein-based nutritionally complete diets fed during gestation and lactation differ in effects on characteristics of the metabolic syndrome in male offspring of Wistar rats. Br. J. Nutr. 2011, 107, 284-294. [CrossRef]

29. Cahill, L.; Peng, C.Y.-C.; Bankovic-Calic, N.; Sankaran, D.; Ogborn, M.R.; Aukema, H.M. Dietary soya protein during pregnancy and lactation in rats with hereditary kidney disease attenuates disease progression in offspring. Br. J. Nutr. 2007, 97, 77-84. [CrossRef]

30. Bellizzi, V.; Cupisti, A.; Locatelli, F.; Bolasco, P.; Brunori, G.; Cancarini, G.; Caria, S.; De Nicola, L.; Di Iorio, B.R.; Di Micco, L.; et al. Low-protein diets for chronic kidney disease patients: The Italian experience. BMC Nephrol. 2016, 17, 77. [CrossRef]

31. Li, A.; Lee, H.-Y.; Lin, Y.-C. The Effect of Ketoanalogues on Chronic Kidney Disease Deterioration: A Meta-Analysis. Nutrients. 2019, 11, 957. [CrossRef]

32. Reeves, P.G.; Nielsen, F.H.; Fahey, G.C. AIN-93 Purified Diets for Laboratory Rodents: Final Report of the American Institute of Nutrition Ad Hoc Writing Committee on the Reformulation of the AIN-76A Rodent Diet. J. Nutr. 1993, 123, 1939-1951. [CrossRef]

33. Seegers, W.H. The Effect of Protein Deficiency on the Course of Pregnancy. Am. J. Physiol. Content 1937, 119, 474-479. [CrossRef]

34. Zeman, F.J. Effect on the Young Rat of Maternal Protein Restriction. J. Nutr. 1967, 93, 167-173. [CrossRef] [PubMed]

35. Zeman, F.J. Effects of Maternal Protein Restriction on the Kidney of the Newborn Young of Rats. J. Nutr. 1968, 94, 111-116. [CrossRef] [PubMed]

36. Brenner, B.M.; Garcia, D.L.; Anderson, S. Glomeruli and Blood Pressure: Less of One, More the Other? Am. J. Hypertens 1988, 1, 335-347. [CrossRef] [PubMed]

37. Barker, D.J.P. The origins of the developmental origins theory. J. Intern. Med. 2007, 261, 412-417. [CrossRef]

38. Langley-Evans, S.C. Hypertension induced by foetal exposure to a maternal low-protein diet, in the rat, is prevented by pharmacological blockade of maternal glucocorticoid synthesis. J. Hypertens 1997, 15, 537-544. [CrossRef]

39. Sherman, R.C.; Langley-Evans, S.C. Early administration of angiotensin-converting enzyme inhibitor captopril, prevents the development of hypertension programmed by intrauterine exposure to a maternal low-Protein diet in the rat. Clin. Sci. 1998, 94, 373-381. [CrossRef]

40. Sahajpal, V.; Ashton, N. Increased glomerular angiotensin II binding in rats exposed to a maternal low protein dietin utero. J. Physiol. 2005, 563, 193-201. [CrossRef]

41. Goyal, R.; Galffy, A.; Field, S.A.; Gheorghe, C.; Mittal, A.; Longo, L. Maternal Protein Deprivation: Changes in Systemic Renin-Angiotensin System of the Mouse Fetus. Reprod. Sci. 2009, 16, 894-904. [CrossRef]

42. Stewart, T.; Jung, F.F.; Manning, J.; Vehaskari, V.M. Kidney immune cell infiltration and oxidative stress contribute to prenatally programmed hypertension. Kidney Int. 2005, 68, 2180-2188. [CrossRef] [PubMed] 
43. Watanabe, I.; Jara, Z.P.; Volpini, R.A.; Franco, M.D.C.; Jung, F.F.; Casarini, D.E. Up-Regulation of renal renin-Angiotensin system and inflammatory mechanisms in the prenatal programming by low-Protein diet: Beneficial effect of the post-weaning losartan treatment. J. Dev. Orig. Health Dis. 2018, 9, 530-535. [CrossRef] [PubMed]

44. Mansuri, A.; Elmaghrabi, A.; AlHamoud, I.; Legan, S.K.; Gattineni, J.; Baum, M. Transient enalapril attenuates the reduction in glomerular filtration rate in prenatally programmed rats. Physiol. Rep. 2017, 5, e13266. [CrossRef] [PubMed]

45. Custódio, A.H.; De Lima, M.C.; Vaccari, B.; Boer, P.A.; Gontijo, J.A.R. Renal sodium handling and blood pressure changes in gestational protein-restricted offspring: Role of renal nerves and ganglia neurokinin expression. PLoS ONE 2017, 12, e0179499. [CrossRef] [PubMed]

46. Langley-Evans, S.C.; Welham, S.J.; Sherman, R.C.; Jackson, A.A. Weanling Rats Exposed to Maternal Low-Protein Diets during Discrete Periods of Gestation Exhibit Differing Severity of Hypertension. Clin. Sci. 1996, 91, 607-615. [CrossRef] [PubMed]

47. Sayer, A.A.; Dunn, R.; Langley-Evans, S.C.; Cooper, C. Prenatal Exposure to a Maternal Low Protein Diet Shortens Life Span in Rats. Gerontology 2001, 47, 9-14. [CrossRef]

48. Langley-Evans, S.C.; Welham, S.J.; Jackson, A.A. Fetal exposure to a maternal low protein diet impairs nephrogenesis and promotes hypertension in the rat. Life Sci. 1999, 64, 965-974. [CrossRef]

49. Nwagwu, M.O.; Cook, A.; Langley-Evans, S.C. Evidence of progressive deterioration of renal function in rats exposed to a maternal low-protein diet in utero. Br. J. Nutr. 2000, 83, 79-85. [CrossRef]

50. Pires, K.M.P.; Aguila, M.B.; Mandarim-De-Lacerda, C.A. Early renal structure alteration in rat offspring from dams fed low protein diet. Life Sci. 2006, 79, 2128-2134. [CrossRef]

51. Welham, S.J.; Wade, A.; Woolf, A. Protein restriction in pregnancy is associated with increased apoptosis of mesenchymal cells at the start of rat metanephrogenesis. Kidney Int. 2002, 61, 1231-1242. [CrossRef]

52. He, X.; Xie, Z.; Dong, Q.; Chen, P.; Li, W.; Wang, T. Dynamic p53 protein expression and phosphorylation in the kidneys of rats that experienced intrauterine growth restriction. Ren. Fail. 2015, 37, 896-902. [CrossRef] [PubMed]

53. Oliver, G.; Sosapineda, B.; Geisendorf, S.; Spana, E.; Doe, C.; Gruss, P. Prox 1, a prospero-related homeobox gene expressed during mouse development. Mech. Dev. 1993, 44, 3-16. [CrossRef]

54. Vartiainen, M.K.; Mustonen, T.; Mattila, P.K.; Ojala, P.J.; Thesleff, I.; Partanen, J.; Lappalainen, P. The Three Mouse Actin-Depolymerizing Factor/Cofilins Evolved to Fulfill Cell-Type-Specific Requirements for Actin Dynamics. Mol. Biol. Cell 2002, 13, 183-194. [CrossRef]

55. Welham, S.J.; Riley, P.R.; Wade, A.; Hubank, M.; Woolf, A.; Hubank, M. Maternal diet programs embryonic kidney gene expression. Physiol. Genom. 2005, 22, 48-56. [CrossRef] [PubMed]

56. Dunford, L.; Sinclair, K.D.; Kwong, W.Y.; Sturrock, C.J.; Clifford, B.L.; Giles, T.C.; Gardner, D. Maternal protein-energy malnutrition during early pregnancy in sheep impacts the fetal ornithine cycle to reduce fetal kidney microvascular development. FASEB J. 2014, 28, 4880-4892. [CrossRef] [PubMed]

57. Manning, J.; Vehaskari, V.M. Postnatal modulation of prenatally programmed hypertension by dietary Na and ACE inhibition. Am. J. Physiol. Integr. Comp. Physiol. 2005, 288, R80-R84. [CrossRef] [PubMed]

58. Siddique, K.; Guzman, G.L.; Gattineni, J.; Baum, M. Effect of Postnatal Maternal Protein Intake on Prenatal Programming of Hypertension. Reprod. Sci. 2014, 21, 1499-1507. [CrossRef]

59. Habib, S.; Zhang, Q.; Baum, M. Prenatal programming of hypertension in the rat: Effect of postnatal rearing. Nephron Extra 2011, 1, 157-165. [CrossRef]

60. Márquez, M.; Cabrera, I.; Serrano, D.; Sterin-Speziale, N. Cell proliferation and morphometric changes in the rat kidney during postnatal development. Anat. Embryol. 2002, 205, 431-440. [CrossRef]

61. Davidson, A.J. Mouse kidney development. In StemBook; Harvard Stem Cell Institute: Cambridge, MA, USA, 2008. [CrossRef]

62. Hartman, H.A.; Lai, H.L.; Patterson, L.T. Cessation of renal morphogenesis in mice. Dev. Biol. 2007, 310, 379-387. [CrossRef]

63. Cullen-McEwen, L.; Armitage, J.A.; Nyengaard, J.R.; Moritz, K.M.; Bertram, J. A design-based method for estimating glomerular number in the developing kidney. Am. J. Physiol. Physiol. 2011, 300, F1448-F1453. [CrossRef]

64. Hoy, W.; Hughson, M.D.; Bertram, J.; Douglas-Denton, R.; Amann, K. Nephron Number, Hypertension, Renal Disease, and Renal Failure. J. Am. Soc. Nephrol. 2005, 16, 2557-2564. [CrossRef] [PubMed] 
65. Rodríguez, M.M.; Gómez, A.H.; Abitbol, C.L.; Chandar, J.J.; Duara, S.; Zilleruelo, G.E. Histomorphometric Analysis of Postnatal Glomerulogenesis in Extremely Preterm Infants. Pediatr. Dev. Pathol. 2004, 7, 17-25. [CrossRef] [PubMed]

66. Goyal, R.; Longo, L.D. Maternal protein deprivation: Sexually dimorphic programming of hypertension in the mouse. Hypertens. Res. 2012, 36, 29-35. [CrossRef] [PubMed]

67. Whitaker, K.W.; Totoki, K.; Reyes, T.M. Metabolic adaptations to early life protein restriction differ by offspring sex and post-weaning diet in the mouse. Nutr. Metab. Cardiovasc. Dis. 2011, 22, 1067-1074. [CrossRef]

68. McMullen, S.; Langley-Evans, S.C. Maternal low-protein diet in rat pregnancy programs blood pressure through sex-Specific mechanisms. Am. J. Physiol. Integr. Comp. Physiol. 2005, 288, R85-R90. [CrossRef] [PubMed]

69. Zambrano, E.; Rodríguez-González, G.L.; Guzman, C.; García-Becerra, R.; Boeck, L.; Diaz, L.; Menjivar, M.; Larrea, F.; Nathanielsz, P.W. A maternal low protein diet during pregnancy and lactation in the rat impairs male reproductive development. J. Physiol. 2005, 563, 275-284. [CrossRef]

70. Rinaldi, J.C.; Justulin, L.A.; Lacorte, L.M.; Sarobo, C.; Boer, P.A.; Scarano, W.R.; Felisbino, S.L. Implications of intrauterine protein malnutrition on prostate growth, maturation and aging. Life Sci. 2013, 92, 763-774. [CrossRef]

71. Winship, A.L.; Gazzard, S.E.; Cullen-McEwen, L.; Bertram, J.; Hutt, K.J. Maternal low-protein diet programmes low ovarian reserve in offspring. Reproduction 2018, 156, 299-311. [CrossRef]

72. Briffa, J.F.; Wlodek, M.E.; Moritz, K.M. Transgenerational programming of nephron deficits and hypertension. Semin. Cell Dev. Biol. 2018. [CrossRef]

73. Xing, Y.; Zhang, J.; Wei, H.; Zhang, H.; Guan, Y.; Wang, X.; Tong, X. Reduction of the PI3K/Akt related signaling activities in skeletal muscle tissues involves insulin resistance in intrauterine growth restriction rats with catch-up growth. PLoS ONE 2019, 14, e0216665. [CrossRef] [PubMed]

74. King, R.; Hill, J.L.; Saha, B.; Tong, Y.; Strutt, B.J.; Russell, M.A.; Morgan, N.G.; Richardson, S.J.; Hill, D. Offspring of Mice Exposed to a Low-Protein Diet in Utero Demonstrate Changes in mTOR Signaling in Pancreatic Islets of Langerhans, Associated with Altered Glucagon and Insulin Expression and a Lower $\beta$-Cell Mass. Nutrients 2019, 11, 605. [CrossRef] [PubMed]

75. Tarry-Adkins, J.; Aiken, C.E.; Ashmore, T.J.; Ozanne, S.E. Insulin-signalling dysregulation and inflammation is programmed trans-generationally in a female rat model of poor maternal nutrition. Sci. Rep. 2018, 8, 4014. [CrossRef] [PubMed]

76. Khazaee, R.; McCaig, L.A.; Yamashita, C.; Hardy, D.B.; Veldhuizen, R.A.W. Maternal protein restriction during perinatal life affects lung mechanics and the surfactant system during early postnatal life in female rats. PLoS ONE 2019, 14, e215611. [CrossRef]

77. Yoon, M.; Won, S.B.; Kwon, Y.H. Altered lipid metabolism in rat offspring of dams fed a low-protein diet containing soy protein isolate. Life Sci. 2017, 174, 1-7. [CrossRef]

78. Campisano, S.E.; Echarte, S.; Podaza, E.; Chisari, A. Protein malnutrition during fetal programming induces fatty liver in adult male offspring rats. J. Physiol. Biochem. 2017, 73, 275-285. [CrossRef]

79. Lim, K.; Zimanyi, M.; Black, M.J. Effect of Maternal Protein Restriction in Rats on Cardiac Fibrosis and Capillarization in Adulthood. Pediatr. Res. 2006, 60, 83-87. [CrossRef]

80. Nascimento, L.; Freitas, C.M.; Silva-Filho, R.; Leite, A.C.R.; Silva, A.B.; Da Silva, A.I.; Ferreira, D.S.; Pedroza, A.A.; Maia, M.B.S.; Fernandes, M.; et al. The effect of maternal low-protein diet on the heart of adult offspring: Role of mitochondria and oxidative stress. Appl. Physiol. Nutr. Metab. 2014, 39, 880-887. [CrossRef]

81. Confortim, H.D.; Jerônimo, L.C.; Centenaro, L.A.; Pinheiro, P.F.F.; Matheus, S.M.M.; Torrejais, M.M. Maternal protein restriction during pregnancy and lactation affects the development of muscle fibers and neuromuscular junctions in rats. Muscle Nerve 2016, 55, 109-115. [CrossRef]

82. De Oliveira, J.C.; Gomes, R.M.; Miranda, R.A.; Barella, L.F.; Malta, A.; Martins, I.P.; Franco, C.C.D.S.; Pavanello, A.; Torrezan, R.; Natali, M.R.M.; et al. Protein Restriction During the Last Third of Pregnancy Malprograms the Neuroendocrine Axes to Induce Metabolic Syndrome in Adult Male Rat Offspring. Endocrinology 2016, 157, 1799-1812. [CrossRef] 
83. Watkins, A.J.; Lucas, E.S.; Wilkins, A.; Cagampang, F.R.; Fleming, T.P. Maternal Periconceptional and Gestational Low Protein Diet Affects Mouse Offspring Growth, Cardiovascular and Adipose Phenotype at 1 Year of Age. PLoS ONE 2011, 6, e28745. [CrossRef] [PubMed]

84. Chisaka, T.; Mogi, M.; Nakaoka, H.; Kan-No, H.; Tsukuda, K.; Wang, X.-L.; Bai, H.-Y.; Shan, B.-S.; Kukida, M.; Iwanami, J.; et al. Low-Protein Diet-Induced Fetal Growth Restriction Leads to Exaggerated Proliferative Response to Vascular Injury in Postnatal Life. Am. J. Hypertens. 2015, 29, 54-62. [CrossRef] [PubMed]

85. Buffat, C.; Boubred, F.; Mondon, F.; Chelbi, S.; Feuerstein, J.-M.; Lelièvre-Pégorier, M.; Vaiman, D.; Simeoni, U. Kidney Gene Expression Analysis in a Rat Model of Intrauterine Growth Restriction Reveals Massive Alterations of Coagulation Genes. Endocrinology 2007, 148, 5549-5557. [CrossRef] [PubMed]

86. Dubois, B.N.; Pearson, J.; Mahmood, T.; Thornburg, K.; Cherala, G. Furosemide Pharmacokinetics in Adult Rats become Abnormal with an Adverse Intrauterine Environment and Modulated by a Post-Weaning High-Fat Diet. Basic Clin. Pharmacol. Toxicol. 2015, 118, 432-439. [CrossRef]

87. Cheng, C.-J.; Lozano, G.; Baum, M. Prenatal programming of rat cortical collecting tubule sodium transport. Am. J. Physiol. Physiol. 2011, 302, F674-F678. [CrossRef]

88. Dagan, A.; Habib, S.; Gattineni, J.; Dwarakanath, V.; Baum, M. Prenatal programming of rat thick ascending limb chloride transport by low-protein diet and dexamethasone. Am. J. Physiol. Integr. Comp. Physiol. 2009, 297, R93-R99. [CrossRef]

89. Alwasel, S.H.; Ashton, N. Prenatal programming of renal sodium handling in the rat. Clin. Sci. 2009, 117, 75-84. [CrossRef]

90. Alwasel, S.H.; Barker, D.J.P.; Ashton, N. Prenatal programming of renal salt wasting resets postnatal salt appetite, which drives food intake in the rat. Clin. Sci. 2012, 122, 485. [CrossRef]

91. Ashton, N.; Al-Wasil, S.H.; Bond, H.; Berry, J.L.; Denton, J.; Freemont, A. The effect of a low-protein diet in pregnancy on offspring renal calcium handling. Am. J. Physiol. Integr. Comp. Physiol. 2007, 293, R759-R765. [CrossRef]

92. Jones, S.E.; White, K.E.; Flyvbjerg, A.; Marshall, S.M. The effect of intrauterine environment and low glomerular number on the histological changes in diabetic glomerulosclerosis. Diabetologia 2005, 49, 191-199. [CrossRef]

93. Zimanyi, M.; Bertram, J.; Black, M.J. Does a Nephron Deficit in Rats Predispose to Salt-Sensitive Hypertension? Kidney Blood Press. Res. 2004, 27, 239-247. [CrossRef] [PubMed]

94. Zimanyi, M.; Denton, K.; Forbes, J.M.; Thallas-Bonke, V.; Thomas, M.C.; Poon, F.; Black, M.J. A developmental nephron deficit in rats is associated with increased susceptibility to a secondary renal injury due to advanced glycation end-products. Diabetologia 2006, 49, 801-810. [CrossRef] [PubMed]

95. Vomhof-DeKrey, E.; Darland, D.; Ghribi, O.; Bundy, A.; Roemmich, J.; Claycombe, K. Maternal low protein diet leads to placental angiogenic compensation via dysregulated M1/M2 macrophages and TNF $\alpha$ expression in Sprague-Dawley rats. J. Reprod. Immunol. 2016, 118, 9-17. [CrossRef] [PubMed]

96. Gonzalez, P.N.; Gasperowicz, M.; Barbeito-Andrés, J.; Klenin, N.; Cross, J.C.; Hallgrimsson, B. Chronic Protein Restriction in Mice Impacts Placental Function and Maternal Body Weight before Fetal Growth. PLoS ONE 2016, 11, e0152227. [CrossRef]

97. Rebelato, H.J.; Esquisatto, M.A.; de Sousa Righi, E.F.; Catisti, R. Gestational protein restriction alters cell proliferation in rat placenta. J. Mol. Histol. 2016, 47, 203-211. [CrossRef]

98. Rebelato, H.J.; Esquisatto, M.A.; Moraes, C.; Amaral, M.E.; Catisti, R. Gestational protein restriction induces alterations in placental morphology and mitochondrial function in rats during late pregnancy. J. Mol. Histol. 2013, 44, 629-637. [CrossRef]

99. Jansson, N.; Pettersson, J.; Haafiz, A.; Ericsson, A.; Palmberg, I.; Tranberg, M.; Ganapathy, V.; Powell, T.L.; Jansson, T. Down-Regulation of placental transport of amino acids precedes the development of intrauterine growth restriction in rats fed a low protein diet. J Physiol. 2006, 576, 935-946. [CrossRef]

100. Marangoni, F.; Cetin, I.; Verduci, E.; Canzone, G.; Giovannini, M.; Scollo, P.; Corsello, G.; Poli, A. Maternal Diet and Nutrient Requirements in Pregnancy and Breastfeeding. An Italian Consensus Document. Nutrients 2016, 8, 629. [CrossRef]

101. Hanson, M.A.; Bardsley, A.; De-Regil, L.M.; Moore, S.E.; Oken, E.; Poston, L.; Ma, R.C.; McAuliffe, F.M.; Maleta, K.; Purandare, C.N.; et al. The International Federation of Gynecology and Obstetrics (FIGO) recommendations on adolescent, preconception, and maternal nutrition: "Think Nutrition First"\#. Int. J. Gynecol. Obstet. 2015, 131, S213-S253. [CrossRef] 
102. Carosso, A.; Zonca, M.; Colla, L.; Borella, F.; Daniele, L.; Benedetto, C. Pregnancy in a woman with recurrent immunoglobulin a nephropathy: A case report. Case Rep. Women's Health 2018, 20, e00074. [CrossRef]

103. Nava, J.; Moran, S.; Figueroa, V.; Salinas, A.; Lopez, M.; Urbina, R.; Gutierrez, A.; Lujan, J.L.; Orozco, A.; Montufar, R.; et al. Successful pregnancy in a CKD patient on a low-protein, supplemented diet: An opportunity to reflect on CKD and pregnancy in Mexico, an emerging country. J. Nephrol. 2017, 30, 877-882. [CrossRef] [PubMed]

104. Kalantar-Zadeh, K.; Gutekunst, L.; Mehrotra, R.; Kovesdy, C.P.; Bross, R.; Shinaberger, C.S.; Noori, N.; Hirschberg, R.; Benner, D.; Nissenson, A.R.; et al. Understanding Sources of Dietary Phosphorus in the Treatment of Patients with Chronic Kidney Disease. Clin. J. Am. Soc. Nephrol. 2010, 5, 519-530. [CrossRef] [PubMed]

105. D'Alessandro, C.; Piccoli, G.B.; Cupisti, A. The "phosphorus pyramid": A visual tool for dietary phosphate management in dialysis and CKD patients. BMC Nephrol. 2015, 16, 9. [CrossRef] [PubMed]

106. Scialla, J.J.; Appel, L.J.; Wolf, M.; Yang, W.; Zhang, X.; Sozio, S.M.; Miller, E.R.; Bazzano, L.A.; Cuevas, M.; Glenn, M.J.; et al. Plant protein intake is associated with fibroblast growth factor 23 and serum bicarbonate levels in patients with chronic kidney disease: The Chronic Renal Insufficiency Cohort study. J. Ren. Nutr. 2012, 22, 379-388.e1. [CrossRef]

107. Cases, A.; Guldris, S.C.; Mas, S.; Gonzalez-Parra, E. Vegetable-Based Diets for Chronic Kidney Disease? It Is Time to Reconsider. Nutrients 2019, 11, 1263. [CrossRef]

108. Jing, Z.; Wei-Jie, Y. Effects of soy protein containing isoflavones in patients with chronic kidney disease: A systematic review and meta-analysis. Clin. Nutr. 2016, 35, 117-124. [CrossRef]

109. Chen, X.; Wei, G.; Jalili, T.; Metos, J.; Giri, A.; Cho, M.E.; Boucher, R.; Greene, T.; Beddhu, S. The Associations of Plant Protein Intake With All-Cause Mortality in CKD. Am. J. Kidney Dis. 2015, 67, 423-430. [CrossRef]

110. Koebnick, C.; Heins, U.A.; Dagnelie, P.C.; Wickramasinghe, S.N.; Ratnayaka, I.D.; Hothorn, T.; Pfahlberg, A.B.; Hoffmann, I.; Lindemans, J.; Leitzmann, C. Longitudinal Concentrations of Vitamin B12 and Vitamin B12-binding Proteins during Uncomplicated Pregnancy. Clin. Chem. 2002, 48, 928-933. [CrossRef]

111. Koebnick, C.; Hoffmann, I.; Dagnelie, P.C.; Heins, U.A.; Wickramasinghe, S.N.; Ratnayaka, I.D.; Gruendel, S.; Lindemans, J.; Leitzmann, C. Long-Term ovo-lacto vegetarian diet impairs vitamin B-12 status in pregnant women. J. Nutr. 2004, 134, 3319-3326. [CrossRef]

112. Elsori, D.H.; Hammoud, M.S. Vitamin D deficiency in mothers, neonates and children. J. Steroid Biochem. Mol. Biol. 2018, 175, 195-199. [CrossRef]

113. Alwan, N.A.; Greenwood, D.C.; Simpson, N.A.; McArdle, H.J.; Godfrey, K.M.; Cade, J.E. Dietary iron intake during early pregnancy and birth outcomes in a cohort of British women. Hum. Reprod. 2011, 26, 911-919. [CrossRef] [PubMed]

114. Foster, M.; Herulah, U.N.; Prasad, A.; Petocz, P.; Samman, S. Zinc Status of Vegetarians during Pregnancy: A Systematic Review of Observational Studies and Meta-Analysis of Zinc Intake. Nutrients 2015, 7, 4512-4525. [CrossRef] [PubMed]

115. Carter, J.P.; Furman, T.; Hutcheson, H.R. Preeclampsia and Reproductive Performance in a Community of Vegans. South. Med. J. 1987, 80, 692-697. [CrossRef] [PubMed]

116. Qiu, C.; Coughlin, K.B.; Frederick, I.O.; Sorensen, T.K.; Williams, M.A. Dietary Fiber Intake in Early Pregnancy and Risk of Subsequent Preeclampsia. Am. J. Hypertens. 2008, 21, 903-909. [CrossRef]

117. Frederick, I.O.; Williams, M.A.; Dashow, E.; Kestin, M.; Zhang, C.-L.; Leisenring, W.M. Dietary fiber, potassium, magnesium and calcium in relation to the risk of preeclampsia. J. Reprod. Med. 2005, 50, 332-344.

118. Grieger, J.A.; Grzeskowiak, L.E.; Clifton, V.L. Preconception Dietary Patterns in Human Pregnancies Are Associated with Preterm Delivery. J. Nutr. 2014, 144, 1075-1080. [CrossRef]

119. Mikkelsen, T.B.; Osterdal, M.L.; Knudsen, V.K.; Haugen, M.; Meltzer, H.M.; Bakketeig, L.; Olsen, S.F. Association between a Mediterranean-type diet and risk of preterm birth among Danish women: A prospective cohort study. Acta Obstet. Gynecol. Scand. 2008, 87, 325-330. [CrossRef]

120. Tieu, J.; Shepherd, E.; Middleton, P.; Crowther, C.A. Dietary advice interventions in pregnancy for preventing gestational diabetes mellitus. Cochrane Database Syst. Rev. 2017, 2017, CD006674. [CrossRef]

121. Hughes, G.J.; Ryan, D.J.; Mukherjea, R.; Schasteen, C.S. Protein Digestibility-Corrected Amino Acid Scores (PDCAAS) for Soy Protein Isolates and Concentrate: Criteria for Evaluation. J. Agric. Food Chem. 2011, 59, 12707-12712. [CrossRef] 
122. Zhang, J.; Liu, J.; Su, J.; Tian, F. The effects of soy protein on chronic kidney disease: A meta-analysis of randomized controlled trials. Eur. J. Clin. Nutr. 2014, 68, 987-993. [CrossRef]

123. Cupisti, A.; D'Alessandro, C.; Ghiadoni, L.; Morelli, E.; Panichi, V.; Barsotti, G. Effect of a soy protein diet on serum lipids of renal transplant patients. J. Ren. Nutr. 2004, 14, 31-35. [CrossRef] [PubMed]

124. Cupisti, A.; Ghiadoni, L.; D’Alessandro, C.; Kardasz, I.; Morelli, E.; Panichi, V.; Locati, D.; Morandi, S.; Saba, A.; Barsotti, G.; et al. Soy protein diet improves endothelial dysfunction in renal transplant patients. Nephrol. Dial. Transplant. 2006, 22, 229-234. [CrossRef] [PubMed]

125. Siefker, K.; DiSilvestro, R.A. Safety and Antioxidant Effects of a Modest Soy Protein Intervention in Hemodialysis Patients. J. Med. Food 2006, 9, 368-372. [CrossRef] [PubMed]

126. Azadbakht, L.; Atabak, S.; Esmaillzadeh, A. Soy Protein Intake, Cardiorenal Indices, and C-Reactive Protein in Type 2 Diabetes With Nephropathy: A longitudinal randomized clinical trial. Diabetes Care 2008, 31, 648-654. [CrossRef]

127. Gentile, M.G.; Fellin, G.; Cofano, F.; Fave, A.D.; Manna, G.; Ciceri, R.; Petrini, C.; Lavarda, F.; Pozzi, F.; D'Amico, G. Treatment of proteinuric patients with a vegetarian soy diet and fish oil. Clin. Nephrol. 1993, 40, 315-320.

128. Teixeira, S.R.; Tappenden, K.A.; Carson, L.; Jones, R.; Prabhudesai, M.; Marshall, W.P.; Erdman, J.W. Isolated Soy Protein Consumption Reduces Urinary Albumin Excretion and Improves the Serum Lipid Profile in Men with Type 2 Diabetes Mellitus and Nephropathy. J. Nutr. 2004, 134, 1874-1880. [CrossRef]

129. Azadbakht, L.; Esmaillzadeh, A. Soy-Protein Consumption and Kidney-Related Biomarkers Among Type 2 Diabetics: A Crossover, Randomized Clinical Trial. J. Ren. Nutr. 2009, 19, 479-486. [CrossRef]

130. Yu, J.; Bi, X.; Yu, B.; Chen, D. Isoflavones: Anti-Inflammatory Benefit and Possible Caveats. Nutrients 2016, 8, 361. [CrossRef]

131. Vitale, D.C.; Piazza, C.; Melilli, B.; Drago, F.; Salomone, S. Isoflavones: Estrogenic activity, biological effect and bioavailability. Eur. J. Drug Metab. Pharmacokinet. 2012, 38, 15-25. [CrossRef]

132. Fanti, P.; Sawaya, B.P.; Custer, L.J.; Franke, A.A. Serum levels and metabolic clearance of the isoflavones genistein and daidzein in hemodialysis patients. J. Am. Soc. Nephrol. 1999, 10, 864-871.

133. Jamilian, M.; Asemi, Z. The Effect of Soy Intake on Metabolic Profiles of Women With Gestational Diabetes Mellitus. J. Clin. Endocrinol. Metab. 2015, 100, 4654-4661. [CrossRef] [PubMed]

134. Zulyniak, M.; De Souza, R.J.; Shaikh, M.; Desai, D.; Lefebvre, D.L.; Gupta, M.; Wilson, J.; Wahi, G.; Subbarao, P.; Becker, A.B.; et al. Does the impact of a plant-based diet during pregnancy on birth weight differ by ethnicity? A dietary pattern analysis from a prospective Canadian birth cohort alliance. BMJ Open 2017, 7, e017753. [CrossRef] [PubMed]

135. Becker, G.J.; Hewitson, T. Animal models of chronic kidney disease: Useful but not perfect. Nephrol. Dial. Transplant. 2013, 28, 2432-2438. [CrossRef] [PubMed]

136. Esposito, C.; He, C.-J.; Striker, G.E.; Zalups, R.K.; Striker, L.J. Nature and Severity of the Glomerular Response to Nephron Reduction Is Strain-Dependent in Mice. Am. J. Pathol. 1999, 154, 891-897. [CrossRef]

137. Ma, L.-J.; Fogo, A.B. Model of robust induction of glomerulosclerosis in mice: Importance of genetic background. Kidney Int. 2003, 64, 350-355. [CrossRef] [PubMed]

138. Dubois, B.; Pearson, J.; Hastings, B.; Mahmood, T.; Chan, T.; Alnakhli, A.; Cherala, G. Maternal low-protein diet alters the expression of real-time quantitative polymerase chain reaction reference genes in an age, sex, and organ-dependent manner in rat offspring. Nutr. Res. 2013, 33, 235-241. [CrossRef] [PubMed]

139. Ozanne, S.E.; Hales, C.N. Catch-up growth and obesity in male mice. Nature 2004, 427, 411-412. [CrossRef]

140. Ozanne, S.E.; Hales, C.N. Poor fetal growth followed by rapid postnatal catch-up growth leads to premature death. Mech. Ageing Dev. 2005, 126, 852-854. [CrossRef]

141. Tarry-Adkins, J.L.; Martin-Gronert, M.S.; Fernandez-Twinn, D.S.; Hargreaves, I.; Alfaradhi, M.Z.; Land, J.M.; Aiken, C.E.; Ozanne, S.E. Poor maternal nutrition followed by accelerated postnatal growth leads to alterations in DNA damage and repair, oxidative and nitrosative stress, and oxidative defense capacity in rat heart. FASEB J. 2012, 27, 379-390. [CrossRef]

142. Lim, K.; Armitage, J.A.; Stefanidis, A.; Oldfield, B.J.; Black, M.J. IUGR in the Absence of Postnatal "Catch-Up" Growth Leads to Improved Whole Body Insulin Sensitivity in Rat Offspring. Pediatr. Res. 2011, 70, 339-344. [CrossRef]

143. Eriksson, J.G.; ForsénT, J.; Kajantie, E.; Osmond, C.; Barker, D.J. Childhood Growth and Hypertension in Later Life. Hypertension 2007, 49, 1415-1421. [CrossRef] [PubMed] 
144. Barker, D.J.; Osmond, C.; Forsen, T.J.; Kajantie, E.; Eriksson, J.G. Trajectories of Growth among Children Who Have Coronary Events as Adults. N. Engl. J. Med. 2005, 353, 1802-1809. [CrossRef] [PubMed]

145. Bonacasa, B.; Siow, R.; Mann, G. Impact of Dietary Soy Isoflavones in Pregnancy on Fetal Programming of Endothelial Function in Offspring. Microcirculation 2011, 18, 270-285. [CrossRef] [PubMed]

146. Miliku, K.; Voortman, T.; Hooven, E.H.V.D.; Hofman, A.; Franco, O.H.; Jaddoe, V.W. First-trimester maternal protein intake and childhood kidney outcomes: The Generation R Study. Am. J. Clin. Nutr. 2015, 102, 123-129. [CrossRef] [PubMed]

147. Baylis, C.; Deng, A.; Couser, W.G. Glomerular hemodynamic effects of late pregnancy in rats with experimental membranous glomerulonephropathy. J. Am. Soc. Nephrol. 1995, 6, 1197-1201. [PubMed]

148. Salas, S.P.; Giacaman, A.; Vio, C.P. Pregnant rats with 5/6 nephrectomy have normal volume expansion despite lower renin and kallikrein. Hypertension 2003, 42, 744-748. [CrossRef]

149. Deng, A.; Baylis, C. Glomerular hemodynamic responses to pregnancy in rats with severe reduction of renal mass. Kidney Int. 1995, 48, 39-44. [CrossRef]

(C) 2020 by the authors. Licensee MDPI, Basel, Switzerland. This article is an open access article distributed under the terms and conditions of the Creative Commons Attribution (CC BY) license (http://creativecommons.org/licenses/by/4.0/). 